\title{
Organization of Physical Therapy Classes for Rehabilitation in the Post-COVID Period
}

\author{
Martirosova T. ${ }^{1, *}$, Poboronchuk T. ${ }^{1}$, Kokova E. ${ }^{2}$, Doroshenko O. ${ }^{3}$ Ivanitsky V. ${ }^{4}$ \\ ${ }^{1}$ Department of Physical Culture and Valeology, M.F. Reshetnev Siberian State University of Technology Science, Krasnoyarsk, Russia \\ ${ }^{2}$ Department of Physical Culture, Siberian Law Institute of the Ministry of Internal Affairs of Russian Federation, Krasnoyarsk, Russia \\ ${ }^{3}$ Siberian Federal University, Krasnoyarsk, Russia \\ ${ }^{4}$ Department of Physical Culture, Siberian Federal University, Russia
}

Received May 19, 2021; Revised August 23, 2021; Accepted September 20, 2021

\section{Cite This Paper in the following Citation Styles}

(a): [1] Martirosova T., Poboronchuk T., Kokova E., Doroshenko O., Ivanitsky V. , "Organization of Physical Therapy Classes for Rehabilitation in the Post-COVID Period," Universal Journal of Public Health, Vol. 9, No. 5, pp. 230 - 234, 2021. DOI: 10.13189/ujph.2021.090504.

(b): Martirosova T., Poboronchuk T., Kokova E., Doroshenko O., Ivanitsky V. (2021). Organization of Physical Therapy Classes for Rehabilitation in the Post-COVID Period. Universal Journal of Public Health, 9(5), 230 - 234. DOI: 10.13189/ujph.2021.090504.

Copyright $\bigcirc 2021$ by authors, all rights reserved. Authors agree that this article remains permanently open access under the terms of the Creative Commons Attribution License 4.0 International License

\begin{abstract}
The purpose of the study is to organize physical therapy classes and develop a program that includes an adapted method of health-improving walking for rehabilitation in the post-covid period. This means of physical culture can provide the maximum level of functional and physical characteristics to achieve high performance, emotional mood, and healthy life activity. The study involved bachelors in the Siberian State Scientific and Technical University named after M. F. Reshetnev, who had been ill with COVID-19. Classes of therapeutic physical culture will allow to reveal the great adaptive potential of the human body, to form a long-term adaptation, which consists in the restructuring of the body at the molecular, cellular level, in tissues, organs, organ systems and intersystem level, which determines the positive morphological and functional features of the trained organism as a manifestation of the biological norm. The frequency, intensity, direction of physical exercises, their duration and combination, the level of fitness, individual characteristics of those engaged and a number of other factors determine the nature and degree of these changes in the body. In future studies, we plan to use health-improving walking for rehabilitation in the period after AIDS for university teachers aged 50-59 years, as the most vulnerable during the COVID-19 pandemic. In conclusion, it should be noted that when exposed to physical exertion, muscle fibers are regenerated, becoming overgrown with a larger amount of protein material than it
\end{abstract}

was originally. That is why the physical capabilities of the muscles are improved, due to the distribution of the load on a larger amount of muscle tissue. The synthesis of more muscle fiber requires the delivery of more oxygen and nutrients to the cells not only of the muscles, but also of all body systems. Increased blood flow contributes to an increase in the lumen of blood vessels, which increases the efficiency of the cardiovascular system, which is especially important during rehabilitation in the post-covid period.

Keywords COVID-19, Rehabilitation, Recreational Walking, Motor Activity, Post-COVID Period, Wellness Walking, Cardiovascular System, Fatigue

\section{Introduction}

The following contradictions were identified in the process of analyzing the scientific and methodological literature: between the necessity of restoring the Russian population's health in the post-ovoid period and the lack of organization of human motor activity for rehabilitation in the post-ovoid period after a new underinvestigated viral infection; between the need to develop a biopedagogic wellness technology of human motor activity for rehabilitation after a new poorly studied viral infection in the post-covid period, including a program of adapted 
wellness walking, and the organization of therapeutic physical culture engagement; between the necessity of holding classes in therapeutic physical culture and the laziness of a person's personality. COVID-19 is characterized by the same symptoms as acute respiratory viral infection: elevated body temperature $(>90 \%)$; cough (dry or with little sputum) in $80 \%$ of cases; shortness of breath $(55 \%$ of the cases); myalgia and fatigue $(44 \%)$; feeling of tightness in the chest $(>20 \%)$. In a severe case of COVID-19, rapid progression of airway disease, respiratory failure, and other complications are present. After recovery, the patient has lasting weakness, impaired muscle tone as a result of the positioning of a patient's body (especially while on artificial lung ventilation), peripheral nerve damage, and certain psychological problems such as depression and anxiety. The virus may affect the central nervous system, resulting in COVID encephalopathy. There have been cases of COVID brain damage, COVID meningitis and encephalitis. COVID infection can affect the cardiovascular system: signs of heart failure, shortness of breath, rhythm disturbances. There are cases of covid myocarditis, lesions of the conducting system of the heart. The virus affects the gastrointestinal tract, and lesions of the liver may occur - changes in its function and a marked increase in liver enzymes, which are due to the effects of the virus and the large amount of medication that patients receive. Coronavirus can affect virtually any organ and system in the body $[1-6,12]$. The problem is that it is very difficult to achieve a stable remission and rapid rehabilitation of the body after a COVID-19 infection, so this problem needs to be addressed by specialists in borderline areas of knowledge: psychologists, teachers, specialists in physical culture and sports.

\section{Background of the Problem}

Right before the end of 2019, in December, new spreading infections of coronavirus was being reported. In February 2020, the World Health Organization named the infection COVID - 19, which was caused by a new pathogen. Coronavirus can cause cognitive impairment (memory loss), prolonged anxiety depressive states, can affect the respiratory system and cause progressive respiratory diseases and other complications. The most severe forms are more often developed in elderly patients (60 years or more) with concomitant diseases. Currently, it is difficult to deal with the virus itself and its consequences, so in order to revive the former patients' health in the post-COVID period, a correct program of their rehabilitation is necessary.

According to scientists, for rehabilitation in the post-ovoid period, the most significant is reactivity (the ability of the body to respond to changes in vital activity to changes in the internal and external environment), individual reaction of a living object at the individual level; physiological reactivity certain forms of reaction to the action of environmental factors that do not violate the self-regulation of the body; pathological reactivity reaction to the action of pathogenic factors that cause damage to structures and violation of self-regulation; specific immunological reactivity - the ability of the body to respond to the action of an antigen by producing antibodies or a complex of cellular reactions specific to this antigen; non - specific reactivity-a complex of changes in the body that occur in response to external factors that are not related to the immune response (for example, changes in the body in response to hypoxia, the effect of accelerations, overloads, etc.) [6,11].

Non-specific reactivity is not related to the immune response - it is a complex of changes in the body that occur in response to external factors: changes in the body in response to hypoxia, the effect of accelerations, overloads, etc. Therefore, it is important for us and it may be interesting to form such positive changes to improve the stability of the body during physical adaptation in the process of motor activity with progressive loads up to overloads at health-improving classes of therapeutic physical culture for the purpose of rehabilitation in the post-ovoid period.

A person is able to change the environment for himself. The need to adapt to the environment leads to the fact that a person is always on the move, motor activity is his biological need. Therefore, it is currently necessary to use it as the main means of rehabilitation in post-ovoid conditions.

During the classes of therapeutic physical culture, it is through non-specific reactivity that a person improves the condition of his body (blood flow increases, which helps to improve the trophic of cells and tissues, bone density increases, the distribution of physical load on the muscles improves), gradually reaching higher levels and adaptation opportunities without overloads and stresses. To adapt with a gradual increase in physical activity from the current level, to adapt to loads that do not reach overloads $[7,10]$.

The vital activity of each person's body can be characterized by a genotype-inherited morphological and functional properties and qualities transmitted by parents, as well as a phenotype - acquired after birth under certain conditions of individual development. The physical development of the body is considered to be the total manifestation of these properties and qualities (genotype and phenotype) in the form of age-related features of neuropsychic activity, physical strength and endurance, determined by the state of morphological and functional characteristics.

\section{Methodology}

Under the pedagogical methodology, we understand the 
methodology and organization of the study, which in our work represents the basis of health-improving classes of therapeutic physical culture in the post-ovoid period, including cyclic aerobic exercises, in which at least two-thirds of all muscle groups of the human body participate. We have performed a search and collection of information sources (articles, conference materials, abstracts of reports, journals). A set of scientific methods was used in the study, including pedagogical observation, testing, and questionnaires. The method of analyzing literary sources allowed us to substantiate and develop a program of adapted health-improving walking as the simplest and_most effective means of therapeutic physical culture in the post-ovoid period. The health and preventive effect of walking depends on increasing the body's ability to absorb (consume) oxygen, i.e. on the aerobic capabilities of the body. Walking performed for 30 minutes leads to an increase in oxygen consumption, an increase in the aerobic capabilities of the body. The aerobic capabilities of the body are determined by the indicators of maximum oxygen consumption (MPC), which the body can use in the process of extremely strenuous work in cyclic exercises. Acyclic sports (sports games, gymnastics) are inferior to cyclic ones in this respect. The duration of classes is at least 30 minutes, and the intensity does not exceed the anaerobic threshold (AP) of the level of intensity (speed of movement), at which the energy demand of the muscles is fully provided by oxygen sources - the oxidation of carbohydrates and fats with oxygen. When the anaerobic threshold is exceeded, there is not enough oxygen, and the body is forced to use oxygen - free sources (the breakdown of muscle glycogen-glycolysis and creatine phosphate with the formation of oxygen debt and the accumulation of lactic acid in the muscles). Wellness walking as a type of aerobic exercise has a pronounced preventive effect against cardiovascular diseases, which is so important in the post-ovoid period. The basis of any wellness program should be aerobic exercises. With the growth of the aerobic capabilities of the body (MPC), the risk factors for cardiovascular diseases also decrease, there is a prevention of colds and health promotion, the release of endorphins into the blood helps to raise the mood, there is an increase in the mental and physical performance of the body, fat burning occurs while walking. In the presented study, we recommended health-improving walking as the simplest, most affordable and effective means in the organization of human motor activity for rehabilitation in the post-ovoid period. Wellness walking relieves emotional stress, cognitive disorders, anxiety-depressive states, burns excess adrenaline, adipose tissue, normalizes the processes of arousal and inhibition in the central nervous system, which is so important in the post-ovoid period. Wellness walking normalizes the body's lipid metabolism, reduces the level of cholesterol, which is responsible for the development of atherosclerosis.
Increases the level of high-density lipoproteins that prevent its development [1,7-9]. This skill is the most durable, stable, automated motor act formed in the first years of life on the basis of an innate walking reflex. Running differs from walking by the presence of a flight phase. The landing of the foot in running causes a shake of the body and a shock wave that reaches the joints and spine. This shaking has a positive effect on the internal organs, the walls of blood vessels, but has a negative effect on the joints of a person. The effect of walking on the human body is much milder, so it has no contraindications. One necessary condition is aerobic endurance, which is necessary for the prevention of diseases, raising the emotional state of the body, relieving tension, develops only with prolonged, continuous walking at sufficient intensity (speed). In the classes of health-improving walking, the effect of capillarization of the heart muscle is no less important, that is, the formation of new, bifurcation, elongation of capillaries that improve blood supply and myocardial trophism. With an increase in the fitness of the heart muscle, the contractile ("pumping") function of the heart increases. Wellness walking is active walking at a speed of $6.5-7.0 \mathrm{~km} / \mathrm{h}$, when the muscles of the lower leg and pelvis are included in the work, due to the flexion of the ankle joint, the feet are actively repelled from the support, the shock wave of which reaches the joints and spine and sharply dampens the speed. The foot should fall on the support with the heel with a soft roll to the toe, avoiding a shock wave along the longitudinal axis of the lower extremities. If, when walking, a tendency to turn the foot inward (clubfoot) is formed - this can lead to a chronic injury of the ankle joint, both feet should be placed parallel while walking. Such walking occupies an intermediate position between walking and sports. The analysis of the results of the study on the organization of human motor activity in the process of rehabilitation revealed a decrease in motor activity in the post-ovoid period. For the rehabilitation of the body in the post-ovoid period with the use of recreational walking, it is necessary to walk a distance of 6-6. $5 \mathrm{~km}$ per hour every day. Physical therapy classes should be clearly planned, the daily diet should contain a set of basic components of proteins, fats, carbohydrates, minerals, including high-quality water, vitamins.

\section{Results and Finding}

The study involved students who had been ill with COVID-19, engaged in a special medical group of the Siberian State University of Science and Technology named after M. F. Reshetnev. The first stage - 3 months, used health-improving walking twice a week for 20 minutes. The duration of walking was increased gradually over 6 months to 40 minutes at one speed. An environmentally friendly route was chosen for the classes, 
the walking speed was measured using a digital application. Heart rate was measured at the beginning and at the end of the route. The second stage - the next 3 months, gradually increased the walking speed without increasing the distance. With an increase in fitness, the walking speed was gradually increased by a small amount. The transition of breathing through the nose to breathing through the mouth (when it is necessary to take an additional breath through the mouth) indicates that there is no adaptation to this particular load value, its own optimal speed is exceeded, therefore, the pace of walking must be reduced. In the next three months, we set the goal of the lessons - to perform the Gibbs control test (Australian doctor): measuring heart rate after walking at a distance of $5 \mathrm{~km}$ in 45 minutes at a calm pace without undue stress. At this stage, the heart rate was $90-120$ beats/ min. The third stage (next 3 months) is the stage of stabilisation and maintenance of physical performance. If adaptation is taken into account, the number of activities was increased to four times a week, a distance of $5 \mathrm{~km}$ in $45 \mathrm{~min}$, energy expenditure of $2000 \mathrm{kcal}$ per week, which represents the energy threshold in the post- covid period. The developed programme included health walking, which has various complex effects on the human body. Above all, it is the expenditure of energy, fats and carbohydrates in proportion to the duration and speed of walking. Recreational walking is a means of providing energy expenditure through the contraction of almost all muscles. Daily recreational walking at $6 \mathrm{~km} / \mathrm{h}$ provided an energy expenditure of $0.7 \mathrm{kcal}$ per $1 \mathrm{~kg}$ of body weight per $\mathrm{km}$ walked. Under these conditions, a person weighing $70 \mathrm{~kg}$ consumed about $350 \mathrm{kcal}$ in one hour, while the weekly expenditure was 2,000 kcal, which provided a minimum threshold for missing energy expenditure. It was the expenditure of this amount of energy that promoted cardiovascular recovery in the post-covid period. Recreational walking was characterized by another feature - the expenditure of energy during walking - complex fats and triglycerides, which directly threaten the health and are also responsible for the development of cardiovascular disease. To provide energy for muscle activity the body's carbohydrate and fat resources were expended. The oxidation of $1 \mathrm{~g}$ of carbohydrate required $5.0 \mathrm{kcal}$ of energy, whereas $1 \mathrm{~g}$ of fat required $9.3 \mathrm{kcal}$. Fats provided twice as much energy during oxidation as carbohydrates but were more difficult to oxidise as they required significantly more oxygen. Carbohydrates are more easily oxidized than fats, so during intense activity (e.g. fast running), it is carbohydrates, not fats, that deliver energy to the muscles. The lower the intensity, the more fat is consumed, and conversely, the higher the speed of movement (running), the greater the role of carbohydrates in energy supply. However, it is fats, not carbohydrates that need to be consumed to be healthy. Therefore, although walking speed is slower than running speed, walking is optimal as a type of exercise for normalising lipid metabolism, rehabilitation in the post-covid period. Recreational walking influenced the circulatory system and increased the aerobic capacity of the body (IPC), leading to normalisation of blood pressure, both low and high. This is explained by the normalisation of vascular tone, the tension of blood vessel walls, on which blood pressure depends. Recreational walking caused the lumen of the smallest vessels - capillaries, which are responsible for blood and oxygen delivery to the muscles, to expand, which led to the reduction of systolic blood pressure. The smaller the lumen, the higher the pressure on the vascular wall, the wider the diameter of the vascular lumen, the less pressure on the vascular wall. Hypotension (low blood pressure) is more resistant to aerobic exercise, but with regular exercise, there is an increase in blood pressure, up to complete normalisation, which is due to improved regulation of vascular tone by the central nervous system and increased elasticity of arterial walls $[6$, 8].

The effect of health walking in physical therapy classes became an additional motivation for motor activity. The developed program included a "self-monitoring diary" in which we evaluated the results of the Gibbs test, walking duration, heart rate before the beginning, in the middle of the class and in the recovery period, the number of classes conducted, the account of the number of steps when walking. The results of the measurements made it possible to establish connection between the duration of walking and the number of steps per lesson. In our study, the average duration was between 54 and 44 minutes. The total number of movements per lesson ranged from 110455 to 65042 , which in terms of 113 steps and 87 steps per minute or 6,136 steps in the first case and 3,826 steps in the second, per lesson.

The results of health-improving walking of a person with a change in heart rate (HR) are presented by the following indicators. The average duration of the lesson was 33 minutes. The average heart rate before classes was 72 beats / $\min (p<0.05)$, in the middle of classes, the first measurement recorded an average of 124 beats $/ \mathrm{min}$ $(p<0.05)$, the second -139 beats $/ \min (p<0.05)$. At the first minute, the heart rate recovery was 156 beats $/ \mathrm{min}$ $(p<0.05)$, at the third -124 beats $/ \min (p<0.05)$. First of all, it should be noted that the need for recreational walking in the post-ovoid period is caused by a vital need, when there is not enough time for recreation. Rhythmic wellness walking has its advantages. It is available, not costly financially. Each student was given the opportunity to restore health in the process of practicing therapeutic physical culture with the use of recreational walking, as well as individually develop themselves through a conscious desire to overcome laziness, take into account the harmonious combination of physical and psychological qualities through mental-image thinking activity. 


\section{Conclusions}

In the experimental work, the effectiveness of therapeutic physical culture classes with the use of recreational walking for the rehabilitation of a person is theoretically justified and verified, taking into account the medical and biological properties of the body and the specifics of the human condition in the post-ovoid period.

The theoretical justification of health-improving walking gave an idea to those engaged in the post-ovoid period about the benefits of turning to natural human movements, when the rhythm and pace of movement, the rhythm of walking with breathing, are harmoniously combined. For psychological recovery and the creation of a positive emotional background, the mental (imaginative, mental) work of the students is important. The energy expenditure of the body in the conditions of constantly repeated contact of the feet with the support during natural movement on its surface brought satisfaction from overcoming oneself through the created difficulty in physical exertion during health-improving walking. It is this algorithm of movements that can extinguish anxiety-emotional and stressful states in the post-ovoid period, which is so important for a person who has been ill.

\section{REFERENCES}

[1] Abdullaev R.Yu., Komissarova O.G. Laboratorny`e proyavleniya koronavirusnoj infekcii COVID-19. Vrach. 2020. - T. 31. - № 5. - P. 3-5.

[2] Molekulyarnaya genetika, mikrobiologiya i virusologiya. 2020. - T. 38. - № 2. - P. 51-58.

[3] Viktorov V.V., Ahmerova S.G., Nazarova E.M., Hismatullina G.YA. Organizaciya podgotovki specialistov dlya raboty $\mathrm{V}$ usloviyah rasprostraneniya novoj koronavirusnoj infekcii COVID-19. Medicinskij vestnik Bashkortostana. - 2020. - T. 15. - № 3 (87). - pp. 40-44.

[4] Bevova M.R., Netesov S.V., Aul'chenko Yu.S. Novaya koronavirusnaya infekciya COVID-19. Zheleznova A.D., Bufetova A.M. Diagnostika koronavirusnoj infekcii. Medicinskoe obrazovanie segodnya. - 2020. - № 3 (11). - P. 140-149.

[5] Ostrovskij D.I., Ivanova T.I. Vliyanie novoj koronavirusnoj infekcii COVID-19 na psihicheskoe zdorovje cheloveka (obzor literatury). Omskij psihiatricheskij zhurnal. - 2020. No. 2-S1 (24). - pp. 4-10.

[6] Prilutskaya M., Mendualieva T., Corazza O. Emotional reactions and coping strategies of medical students during the covid-19 pandemic: an online cross-sectional study. Science \& Healthcare. - 2020. - T. 22. - № 4. - pp. 5-14.

[7] Razumov A.N., Ponomarenko G.N., Badtieva V.A. Medicinskaya reabilitaciya pacientov $\mathrm{s}$ pnevmoniyami, associirovanny'mi s novoj koronavirusnoj infekciej COVID-19. Voprosy` kurortologii, fizioterapii i lechebnoj fizicheskoj kul tury`. - 2020. - T. 97. - № 3. - P. 5-13.

[8] Sinolicz M.A., Agapov P.V. Mery` obespecheniya nacional noj bezopasnosti $\mathrm{v}$ usloviyax rasprostraneniya novoj koronavirusnoj infekcii $\mathrm{v}$ Rossijskoj Federacii i drugix stranax. Vestnik Yuridicheskogo instituta MIIT. 2020. - № 2 (30). - P. 54-61.

[9] Starshinova A.A., Kushnareva E.A., Malkova A.M., Dovgalyuk I.F., Kudlaj D.A. Novaya koronavirusnaya infekciya: osobennosti klinicheskogo techeniya, vozmozhnosti diagnostiki, lecheniya i profilaktiki infekcii u vzrosly`x i detej. Voprosy`sovremennoj pediatrii. - 2020. T. 19. - № 2. - P. 123-131.

[10] Tkachenko O.V. Urazhennya nervovoï sistemi pri koronavirusnij infekcziï COVID-19. Ukrainskij nevrologicheskij zhurnal. - 2020. - № 1-2 (54-55). -P. $5-12$.

[11] Shmonin A.A., Mal`ceva M.N., Mel`nikova E.V., Mishina I.E., Ivanova G.E. Medicinskaya reabilitaciya pri koronavirusnoj infekcii: novy`e zadachi dlya fizicheskoj i reabilitacionnoj mediciny” v Rossii. Vestnik vosstanovitel `noj mediciny’. - 2020. - № 3 (97). - P. 14-21.

[12] Mohammed Hasan , Marie Ma'abreh , Anas Ramadan Ibrahim Al-Masri, "Attitude towards Coronavirus Pandemic "Covid-19" and Its Relationship to Optimism and Pessimism among a Sample of Residents in Irbid," Universal Journal of Public Health, Vol. 9, No. 1, pp. 1 - 17, 2021. DOI: 10.13189/ujph.2021.090101. 